\title{
Research on Instructors' Professional Ethics Building from the Perspective of Specialization Dong Long
}

(Zhuhai College of Jilin University, Guangdong Zhuhai, 519041)

\begin{abstract}
Professional ethics building plays an important role in instructors' specialization, which helps them better fulfill career responsibilities, meets the needs of society and improves regulations and roles for professional development. Studies on professional ethics relationships and regulations for instructors enable professional ethics become basic ethics and act codes abode by them. building professional ethics for instructors' specialization in higher education so as to be identified and abode by them, them turning into their values and practical actions in reality.
\end{abstract}

Keywords: Mentor; Professional ethics; Professional

\section{专业化视阈下的辅导员职业伦理建构研究}

\author{
龙东 \\ (吉林大学珠海学院, 广东珠海 519041 )
}

摘要: 辅导员专业化进程中职业伦理建构有着重要意义, 它是辅导员更好地履行职业责任, 满足社会需要, 促进专业化 发展的行为规范和准则。对辅导员职业伦理关系、伦理规范建构等问题进行研究, 使职业伦理成为辅导员工作中应遵循的基 本伦理规范和行为准则, 构建高校辅导员专业化发展中的职业伦理, 为辅导员自身所认同和遵守, 在实际工作中转化成辅导 员的价值理念和实际行动。

关键词: 辅导员; 职业伦理; 专业化

引言

高校辅导员专业化、职业化建设一直是高校思想政治教育工作研究的热点。自中共中央、国务院《关 于进一步加强和促进大学生思想政治教育的意见》（中发 [2004]16 号）文件颁布以来, 高校辅导员队伍建 设发生了深刻的变革，在辅导员的选拔培养、待遇保障、发展空间等方面已经形成一套完整的机制体系。 2014 年 4 月教育部颁布实施的《高等学校辅导员职业能力标准 (暂行)》 (以下简称 “能力标准” ) 从辅导 员职业概况、基本要求和职业等级能力标准对辅导员队伍建设进行了规范和要求, 进一步推动了高校辅导 员专业化和职业化建设进程。

职业伦理是指职业活动中的伦理关系及其调节原则, 它是根据社会系统中的角色及其功能要求，获得 具体社会角色及其权利与义务、责任的规定，体现了特定的价值理念和特殊的伦理关系 [1]。它是人在社 会化过程而逐渐形成的, 并从社会伦理的视角确立职业的伦理规范及价值观问题, 是现代社会伦理建构中 不可或缺的部分, 它更强调的是职业成员对 “总体性的社会伦理和社会主导价值观的遵循”。辅导员的职 业伦理作为一种职业道德的规范和标准, 它能促使辅导员在进行自己的职业活动时, 选择符合道德要求的 职业行为。目前理论界缺少对辅导员职业伦理的相关研究, 对辅导员职业伦理的研究呈现表层化, “高校 辅导员职业伦理在微观上表现为辅导员工作实践的一种必然性, 它有很强的实践特性” [2]。但在专业化 进程中对辅导员职业伦理更多专倾向于工具理性, 缺乏系统性和可操作性, 以至于辅导员专业化进程发展 缓慢。 


\section{1 高校辅导员专业化发展中的职业伦理建构的必要性}

\section{1 构建职业伦理是高校辅导员专业化发展的必然要求}

从理论研究上看, 伦理指人在社会生活关系中应当遵循的道理与规则, 或专指社会的秩序、规则以及 人们合理正当的行为。职业伦理是某种职业的从业人员以伦理自然为基础, 根据本行业的专业知识, 经过 逻辑推演形成的行为规范, 它也是从业者对他从事工作和服务的对象所承担的责任。辅导员职业伦理是高 校辅导员以专业的理念和精神为基础, 根据大学生思想政治教育工作的理论与实践知识, 经过最初的一般 性德性要求演变成具有道德法典意义的职业规范, 它是高校辅导员队伍为更好地履行职业责任, 满足社会 需要, 促进专业化发展的行为规范和准则。从 2004 年的中央 16 号文件和教育部 24 号令开始, 我国的辅 导员队伍建设就一直在专业化的进程中推进, 现实问题是, 对高校辅导员专业化的研究过多专注于工具理 性, 更多地关注辅导员的职业活动, 缺少了辅导员职业伦理的研究。而辅导员在社会生活中各项活动的开 展以及辅导员职业伦理实体的形成与发展, 都是在辅导员职业伦理发挥规范、调节、促进的作用下完成的。 因此，构建职业伦理是高校辅导员专业化发展的必然要求。

\section{2 构建职业伦理是高校辅导员开展职业活动的内在要求}

纵观十年来高校辅导员队伍专业化发展路径, 从 16 号文件对辅导员具有教师和干部的双重身份的认 定, 教育主管部门和高校对辅导员的准入、使用、培训考核和评价机制的确立, 到高校辅导员能力标准的 颁布实施, 高校辅导员队伍专业化的发展研究更过体现在外显的技能层面的建设, 缺乏对辅导员队伍发展 的伦理考量, 使得辅导员专业化发展中缺少了一定道德标准。辅导员工作作为一种职业活动需要一般的职 业道德向职业伦理转换, 在工作中辅导员面临着与教师、学生、社会、以及自身发展等诸多因素, 使得辅 导员在职业活动中面临着多元和复杂的规范体系和行为评价标准, 亟需建立相对统一的职业伦理和行为规 范体系。职业伦理在辅导员工作中的具体体现应由职业理想、职业精神、职业良性、职业态度、职业关系， 以及学术活动的职业行为规范等几部分组成, 它们以为专业伦理为基础, 并有机结合了高校辅导员职业个 性[3]。

新颁布实施的 “能力标准” 对辅导员在思想政治教育、党团和班级建设、学业指导、日常事务管理、 心理健康教育与咨询、网络思想政治教育、危机事件应对、职业规划与就业指导、理论和实践研究九个方 面的职业能力提出了初、中、高级的标准要求。这种复合的职业能力要求使得辅导员与学生之间的关系不 同于一般的师生职业伦理关系, 更需要建构符合辅导员职业能力要求的伦理体系。随着社会形态发展以及 时代要求, 辅导员职业活动也发生了巨大的变化, 从单一的 “思想政治工作者” 已演变成学生思想政治教 育、学生事务管理、学生发展指导为一体的大学生人生导师, 职业伦理构建已成为高校辅导员队伍专业化 发展的内在要求。

\section{3 构建职业伦理是解决辅导员职业困境的现实需要}

在高校辅导员专业化发展的发展进程中，为帮助辅导员做好角色定位，逐步制定了详细的专业标准。 但是辅导员职业活动本身具有独特性, 辅导员也面临着特殊的职业困境, 例如: 辅导员选拔任用上标准空 泛, 缺乏详细具体的专业化要求, 以及在辅导员的培训体系不健全, 缺乏完善的专业化培训机制。辅导员 职业有其特殊的特点, 辅导员职业活动决定着学生的政治方向, 影响着学生的世界观、人生观、价值观, 一定程度上左右着他们未来的发展, 这就要求辅导员必须具有良好的职业伦理, 要热爱自己所从事的职业, 
要立志于为教育事业奉献终身, 要关爱每一名学生, 要认真负责地对待每一项具体工作。辅导员职业伦理 的缺失, 将会对辅导员队伍建设、学生的思想政治教育、以及高等教育的发展造成不可估量的损失。据此, 要不断强化对辅导员职业伦理教育, 使他们能够清晰认识到自己的问题并指导如何及时去改正, 使他们能 够找到努力的方向，能够重新确立自己的职业理想，重新感受到自己的职业归属。

\section{2. 高校辅导员专业化发展中的职业伦理范畴}

\section{1 责任伦理}

责任伦理是以道德责任为基础, 职业道德责任的产生是指人们基于社会伦理基础上, 从业者在内心信 念和伦理责任感的推动下, 自觉履行应尽的职责、使命和义务, 满足社会对职业的伦理要求。辅导员责任 伦理以辅导员职业责任感为基础, 最终目标是将学生培养成有发展、为社会和国家所需要的人, 但辅导员 责任伦理却不是辅导员本人内心所能支配的, 受到外界的影响, 按照道德规范进行职业活动, 是从业者切 实履行伦理准则的行为, 从而在职业活动中形成 “应该做的” 的职业规范意识。责任伦理中辅导员职业心 态多是服从与执行, 工作中按照既定的要求完成各项工作, 对辅导员道德责任更多专注于工作中的量化指 标体系, 在日常工作中缺少主动性的创新, 长期以往下去, 辅导员工作更多注重的则是工具理性, 缺少对 伦理精神的培养。《高等学校辅导员职业能力标准 (暂行)》中对辅导员职业概况、基本要求和职业等级能 力标准做了详细的规范和要求，进一步定位了辅导员职业伦理中的责任伦理方向。

\section{2 良心伦理}

在人类社会活动中，良心被称为 “人们行为道德调节器” , 是规范职业道德的一种道义保证。辅导员 的职业良心源于对辅导员职业的认同感, 是将职业活动中被动的责任承担转入内在的对自己职业道德行为 的自我评价及自我调节，集中地体现了在职业活动中辅导员面临价值冲突时的自我教育、自我修养。在以 良心伦理为准则的职业活动中，辅导员更多的是 “自主做”，工作中体现出一定的敬业精神，随着辅导员 职业能力的提升, 工作中的成功感与荣誉感不断增强, 内化了辅导员活动的职业道德, 自觉主动承担辅导 员职业所赋予的职责和义务。辅导员良心伦理表现在工作上的尽职尽责、甘于奉献, 它更能促进辅导员自 身职业能力不断提高以及辅导员工作制度体系的不断完善。

\section{3 价值伦理}

价值伦理是责任伦理与良心伦理的统一, 是辅导员的职业信仰, 也是辅导员职业伦理的最高境界，能 真正体现辅导员人格真、善、美的完善过程。价值伦理明确了辅导员的职业身份和角色定位, 清晰而明确 的职业身份和角色定位是高校辅导员在其本职范围内卓有成效地开展工作的前提和条件 [4]。价值伦理是 建立在辅导员高度认同这一职业，把职业责任、职业道德升华为职业信仰，所有辅导员工作上都有着一致 的价值理想和信念，他们共同以学生的发展作为自身职业发展的终极价值取向。价值伦理体现在辅导员工 作中不仅遵守一定的职业伦理规范, 而且对辅导员职业活动有深切的认同感, 能将职业操守与自己的职业 生涯中的生命体验有机结合起来, 将职业伦理作为自己的生命追求去恪守、护持, 并以此作为自己的安身 立命之本，在职业生涯感悟道德与智慧，充分享受人生的幸福和快乐，追求道德智慧的完满与自足。

\section{3 高校辅导员专业化发展中的职业伦理建构路径}

\section{1 提升辅导员自身在专业化发展中的职业伦理意识}

高校辅导员专业化发展中过多注重的是辅导员职业能力的建设, 缺少对其职业伦理意识的提升, 辅导 
员职业道德的缺失对于其自身发展及其对学生的教育管理都将带来很大的损失 [5]。目前, 社会上包括辅 导员本身对于辅导员职业认同度都很低，对于高校辅导员专业化的前景缺乏足够的信心，对于辅导员职业 能否成长为向其他职业那样的专业化程度表示担心, 因此更需要有相关政策与措施来对辅导员专业化发展 进行保障。在提升辅导员职业伦理意识上, 要让辅导员正确认知自己的工作, 在职业伦理规范上, 一方面 应从 “培养什么样的人” 以及 “怎样培养人” 的高度, 规范自身的职业行为, 践行社会主义核心价值观, 将立德树人作为辅导员自觉遵守的职业伦理守则。另一方面要加强政治理论学习, 提升政治理论素养, 在 对学生的思想政治教育、党团和班级建设、学业指导、日常事务管理、心理健康教育与咨询、网络思想政 治教育、危机事件应对、职业规划与就业指导、理论与实践研究等能力标准所要求的职业活动中践行作为 大学生人生导师和知心朋友的职业伦理要求, 培养自身的职业伦理意识, 克服职业倦急, 提升对辅导员工 作的职业认同。

\section{2 强化高校辅导员专业化发展中的职业伦理制度建设}

中发 [2004] 16 号文件实施十余年来, 辅导员的专业水平与职业素质不断提升, 育人意识与育人能力不 断增强。然而在辅导员的选聘、考核与评价机相对比较宽泛, 职业伦理层面的相关要求并未涉及。为了更 好地完善辅导员专业化发展中的职业伦理的建构, 高校将辅导员职业伦理教育和职业伦理要求纳入辅导员 入职前培养教育和培训体系，建立起辅导员职业伦理的培训机制，制定规范细致的培训和考核制度，定期 组织多方位的、多样化的职业伦理考评。有条件的高校要在辅导员职业技能比赛中增设职业伦理的考核内 容, 建立辅导员职业伦理工作档案, 与辅导员的奖惩、职称和职级晋升挂钩。高校要根据 “能力标准” 建 立科学化、规范化的辅导员职业伦理工作体系, 结合各高校自己特点, 创新低提高辅导员职业活动的行为 规范、伦理知识和伦理技能, 进一步提升辅导员的职业伦理质量。

\section{3 营造良好的高校辅导员职业伦理文化教育环境}

辅导员职业伦理建设不仅仅是辅导员个体道德行为范畴，它更应该体现在辅导员队伍整体职业伦理文 化教育方面, 相对于与辅导员个体道德来说, 职业伦理文化教育环境有着更重要的意义, 它对辅导员队伍 发展、行为规范、团队和谐等具有优先地位。高校要针对辅导员的职业特点与道德理念, 构建符合特色职 业伦理文化教育体系, 形成自身的伦理特质和内在的约束机制, 做好辅导员职业道德的导向。高校要根据 学校特点和专业特色构建辅导员职业伦理文化, 深入挖掘辅导员专业发展中的里程碑事件以及现实社会中 对辅导员职业伦理需求, 广泛开展弘扬职业道德、职业伦理的系列实践活动, 帮助高校辅导员进一步践行 职业伦理准则, 使职业伦理文化成为所有辅导员的基本准则和内心自觉。

\section{致谢}

基金项目：广东省教育科研 “十二五” 规划 2013 年度研究项目（2013JK333); 校党建与思想政治教 育研究课题（2016JZDZ011）。

\section{Acknowledgements}

Fund Project: Guangdong Province educational scientific research "Twelve-Five" plan annual 2013 research project (2013JK333); research project of school party construction and ideological and political education (2016JZDZ011). 


\section{参考文献:}

[1] 朱贻庭. 伦理学大词典 [M], 上海辞书出版社, 2011：269.

[2] 史慧明. 论高校辅导员职业伦理的建构 [J]。思想理论教育, 2015 (5)：93.

［3］李永山. 高校辅导员专业伦理规范的主要范畴与内涵特征 $[J]$ ．思想理论教育导刊，2014．（8）：133.

[4] 殷润林. 高校辅导员专业建设存在的问题与对策[J]．教育探索，2012 (1)：125.

[5] 马小红. 高校辅导员职业能力提升的困境与对策 [J]. 学校党建与思想教育 2014(7)：74.

\section{References:}

[1] Zhu Yiting. Dictionary of Ethics [M], Shanghai Lexicographical Publishing House, 2011:269.

[2] Shi Huiming. On Construction of Professional Ethics of College Counselors [J].Ideological and Theoretical Education, 2015(5):93.

[3] Li Yongshan. Main Category and Connotation Character of College Counselor's Professional Ethics [J].Leading Journal of Ideological and Theoretical Education, 2014.(8):133.

[4] Yin Runlin. Existing Problems and Countermeasures of College Counselor's Professional Construction [J].Education Magazine, 2012(1):125.

[5] Ma Xiaohong. Predicament and Countermeasure of College Counselor's Professional Ability Promotion [J]. Xuexiao Dangjian Yu Sixiang Jiaoyu, 2014 (7):74. 